\title{
Pawpaw Hybrid Genotypes (Asimina triloba (L.) Dunal) Cultivated in the Bucharest Area
}

\author{
Andrei Florin TABACU, Ana Cornelia BUTCARU*, Andreea STAN, Cosmin Alexandru MIHAI, \\ Florin STĂNIC $\breve{A}$
}

University of Agronomic Sciences and Veterinary Medicine of Bucharest, Romania

*corresponding author: anabutcaru@gmail.com

BulletinUASVM Horticulture 77(2) / 2020

Print ISSN 1843-5254, Electronic ISSN 1843-5394

DOI:10.15835/buasvmcn-hort: 2020.0014

\begin{abstract}
Pawpaw or Northern banana (Asimina triloba (L.) Dunal) is the only representative of the Annonaceae family that can be cultivated in temperate areas. The increasing demands from the consumers for this nearly unknown fruit with high nutraceutical potential require specific researches. The aim of this study is to present the fruits pomological characteristics for 23 genotypes analyzed, cultivated in the Bucharest area. For each genotype yield, fruit size, average number of seeds per fruit, average weight of seeds and seeds size were measured. Fruit biochemical analyses as dry matter, total soluble solids, ascorbic acid content, acidity, were done for several genotypes. Fruit quality evaluation through sensorial analyses was conducted for 13 genotypes. The most valuable genotypes from the Experimental field according to the analyses performed and the consumer's preferences are taken in consideration for further research.
\end{abstract}

Keywords: acidity, ascorbic acid, dry matter, Northern banana, total soluble solids

\section{Introduction}

Pawpaw, Northern banana or asimina (Asimina triloba (L.) Dunal), Annonaceae family, has the origin in North America, having the largest edible fruit from the native fruit trees in this continent (Kral, 1960; Willson and Schemske, 1980; Layne, 1996; Pomper et al., 2003). It has a well-proportioned habitus, 3-7 m height, abundant foliage with shiny dark green colour. The fruit is a berry of different shape and size: elongated or reniform, rarely spherical, green-yellowish and weighting between 50 and 500 grams. The flesh in the initial stages is yellow to yellow-orange, very sweet. The fruits ripen in stages, are climacteric (Koslanund et al., 2000) and perishable (Ghena et al., 2004; Stănică, 2012).

Asimina triloba (L.) Dunal is a species with high frost resistance, surviving at -25 to $-30^{\circ} \mathrm{C}$. It is also well adapted to different soil types, preferring loose, well-drained soils rich in organic matter with a neutral or slightly acidic $\mathrm{pH}$. One another important quality it is the resistance to diseases and pests, being easy to grow in the organic system (Stănică, 2012).

In Romania it is known since 1926, when in Pianu Nou, Alba County, Ioan Suciu family obtained plants from some seeds brought from Ohio State, some of them until recently viable (Cepoiu et al., 2004; Stănică, 2012). Other Asimina triloba (L.) Dunal genotypes are currently found in Romania in the 'Dimitrie Brândză' Botanical Garden of the University of Bucharest and other sites of the city, Geoagiu (Hunedoara county), Simeria, Baia Mare (Cepoiu et al., 2004).

The plant is known and appreciated for its highly nutraceutical fruits (Nam et al., 2018), natural compounds (annonaceous, acetogenins) that can be extracted from leaves, bark and twig tissue 
with anticancerogenic and insecticidal properties (Johnson et al., 1996; Ratnayake et al., 1993; McLaughlin et al., 1986; Huang et al., 2003; Avula et al., 2018). Its habitus recommend it as an ornamental plant for landscapes, having special properties in air de-pollution (Szilagyi and Marian, 2011).

In the last 25 years, extended researches were conducted at the Faculty of Horticulture within USAMV Bucharest regarding the potential of this fruit tree and its adaptation in this area (Stănică and Cepoiu, 2003; Cepoiu et al., 2004; Stănică et al., 2004; Cotruț et al., 2005; Stănică et al., 2008; Stănică, 2012). Detailed researches were made in Baia Mare also, including the plant ornamental value (Szilagyi and Marian, 2011; Szilagyi et al., 2016a,b; Szilagyi et al., 2017).

The increasing demands from the consumers for this nearly unknown fruit with high nutraceutical potential require specific researches. The aim of this study is to present the fruits pomological characteristics for more genotypes analyzed, cultivated in the Bucharest area.

\section{Materials and methods}

Description of the study site and experimental design

The experience was placed in the Experimental field of the Faculty of Horticulture in Bucharest, located in the North part of the town.

Biological material

Researches were conducted on 23 genotypes planted on two rows (Fig. 1) at $4.0 \mathrm{~m} \times 2.0 \mathrm{~m}$ distances between plants. The genotypes were noted R1P1 - R1P11, R2P1 - R2P11 and respectively RP. An integrated fruit growing technology was applied.

The most known genotypes from the asimina collection are: 'Allegheny', 'Potomac', 'Simina' (Fig. 2) (a new Romanian selection under registration) (Stănică, 2012; Ștefan et al., 2018).

For morphological and biochemical fruit characterization, the fruits were noted after fruit set in spring and numbered before the harvesting period, determined the yield. Harvesting period was noted for each genotype, beginning with the first fruits harvested (at the moment when they dropped from tree) to the finals. Fruit weight and size were determined for each fruit/genotype, cumulated data being presented for three years (2016-2018). Seed number and weight were calculated for the fruits harvested in 2018. The method for fruit tree assessment was according to Hoza (2014).

Biochemical analyses

Total soluble solids were determined from flesh juice for each genotype (2018 harvest), with a refractive device Kruss DR301-95 (\% Brix) (Yoon, 2005; Saei, 2011; Oltenacu and Lascăr, 2015).

Dry matter and water content of the samples were determined by oven drying for 24 hours at $105^{\circ} \mathrm{C}$ using a UN110 Memmert oven, method used also by Moura et al., (2005), Skupień, (2006), Delian et al., (2011), Corollaro et al., (2014), Mureşan et al., (2014), Ticha et al., (2015), Bezdadea Cătuneanu et al., (2017).

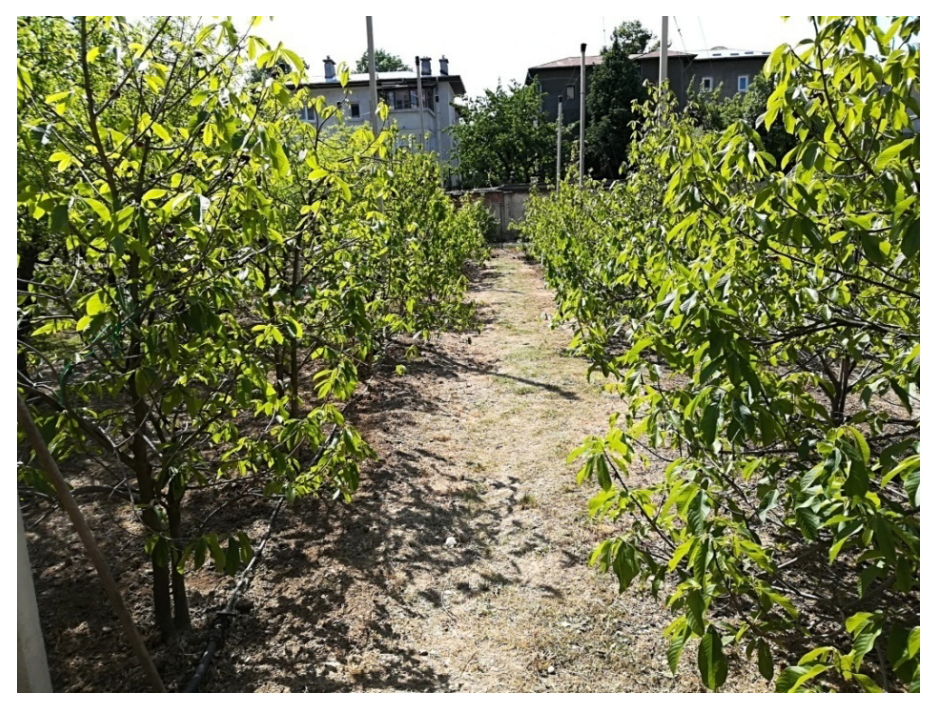

Figure 1. Asimina triloba (L.) Dunal genotypes 


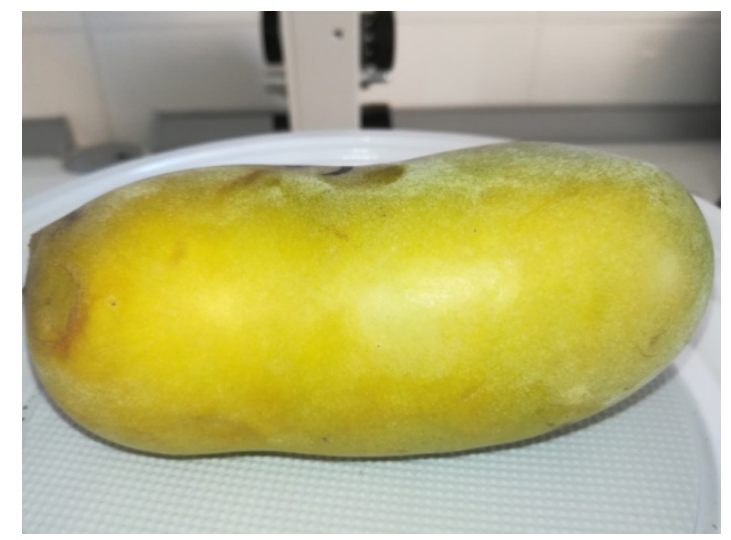

Figure 2. 'Simina' fruit

To determine the content of total titrable acidity, three fruits from the same sample were chosen, removed the skin and the seeds and then crushed the pulp until was obtained a homogeneous paste. $5 \mathrm{~g}$ of the sample with $25 \mathrm{ml}$ double distilled water were titrated with $0.1 \mathrm{~N} \mathrm{NaOH}$, with the TitroLine easy automatic titrator, up to a $\mathrm{pH}$ value of 8.1. The results were calculated according to the following formula and expressed as percentages:

Titratable acidity $(\%)=(\mathrm{V} \times \mathrm{N} \times \mathrm{C} \times 100) / \mathrm{m}$; $\mathrm{V}=$ volume of $\mathrm{NaOH}$ consumed; $\mathrm{N}=\mathrm{NaOH} ; \mathrm{C}=$ equivalent malic acid; $\mathrm{m}=$ mass of the sample. $\mathrm{C}$ has the values: 0.0067 to express acidity in malic acid (Yoon et al., 2005; Saei et al., 2011; Mureşan et al., 2014; Oltenacu and Lascăr, 2015).

To determine the ascorbic acid content three fruits from the same sample were chosen as well, removed the skin and the seeds and crushed the pulp until a homogeneous paste was obtained. The sample preparation consisted of a conventional trituration extraction of $1 \mathrm{~g}$ fresh raw material with $10 \mathrm{ml}$ of orthophosphoric acid (2\%,v/v) for 1 minute. The obtained extract was homogenized for 15 minutes at $500 \mathrm{rpm}$ and then centrifuged for 5 minutes at $7000 \mathrm{rpm}$ and $4^{\circ} \mathrm{C}$. The supernatant obtained by centrifugation was filtered through regenerated cellulose filter (Chanforan et al., 2012; Turmanidze et al., 2017). The chromatographic separation of the compounds was performed using an Agilent Technologies 1200 HPLC equipped with UV-DAD detector through ZORBAX Eclipse XDB-C18 column ( $4.6 \times 50 \mathrm{~mm}, 1.8 \mathrm{pm}$ id). An isocratic elution with formic acid $(0.05 \% \mathrm{v} / \mathrm{v})$, a flow rate of $0.5 \mathrm{ml} / \mathrm{min}$, at $30^{\circ} \mathrm{C}$, and the $2 \mu \mathrm{l}$ injection volume were used. Curve of calibration was obtained by injecting the ascorbic acid stan- dard at different concentrations. Obtained data were processed using Agilent ChemStation B.04.03 software (Agilent, USA).

Sensorial analyzes were performed in several stages on groups formed by persons with random gender, age and occupation. In the initial stage, tests consisted in the evaluation of size, skin colour, taste and flavour (noted from 1 to 10). In the second stage, tests were detailed, fruit scores being accorded to the following differentiation criteria: fruit size, fruit shape, pulp juiciness, pulp colour scored from 1 to 3; aroma rated from 1 to 4; the attractive appearance and the pulp firmness scored from 1 to 5 and taste scored from 1 to 6 .

The analyses were conducted in the Research Center for Studies of Food Quality and Agricultural Products, University of Agronomic Sciences and Veterinary Medicine of Bucharest.

\section{Results and discussions}

Bunch fruits number

One specific element of these species, correlated with the yield, was the number of fruits in a bunch. 'Allegheny' cultivar (Fig. 3 and 4) had the highest number of fruits in a bunch.

\section{Harvesting period}

For the harvesting period, data are presented in Figures 5a and 5b. R1P2 genotype was the earliest in terms of fruit ripening and had the longest harvesting period (77 days in 2018). Other early genotypes were: R1P3, R2P9, R1P10, R2P1 and R2P4. Late harvesting period had R1P1, R1P8 and R2P11 genotypes. The results for several genotypes were similar with Pomper et al. (2008), their genotypes recorded harvesting period bet- 
ween 23-21 days, 18-23 days and respectively 1525 days in three years analyzed.

Yield and morphological fruits parameters

Several genotypes presented continuity in the annual yield, especially in the last two years. Most of them had alternate bearing especially due to climatic factors and crop management. The results were similar with Pomper et al. (2008) experience, regarding discontinuity in production during the analyzed three years $(7.0-15.7 \mathrm{~kg} /$ tree; $3.1-7.7$ $\mathrm{kg} /$ tree; 5.0 - $17.2 \mathrm{~kg} /$ tree).

The most productive genotypes in terms of fruit number/tree were R1P6, R2P1 (every year over 100 fruits/tree) and R2P9 (Tab. 1 and 2).
The average fruit weight presented maximum values in 2018, between 182-190 g for R1P3, R1P9, R1P10 and R2P1 genotypes. The results were similar with Brannan et al. (2015), genotypes fruits analyzed having weight between 84 and $204 \mathrm{~g}$, fruit length between 7.9 and $11.1 \mathrm{~cm}$ and diameter between $4.6-6.4 \mathrm{~cm}$. Pomper et al. (2008) presented fruit weight variation between $76-176 \mathrm{~g}, 84-189 \mathrm{~g}$ and respectively $65-185 \mathrm{~g}$ in the three year experience. The results were also similar with Szilagy et al. (2016a) with a six years fruit monitoring experience.

Generally, the fruit shape (height/average diameter) was elongated.

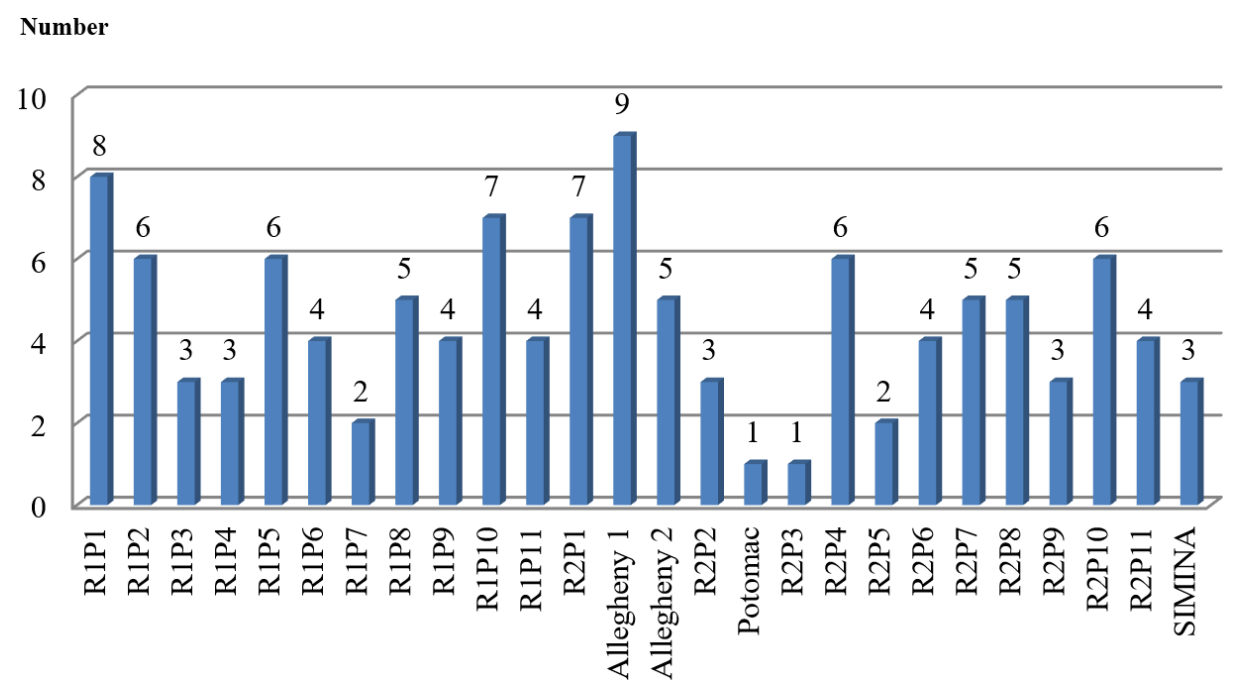

Figure 3. Number of fruits in a bunch/tree

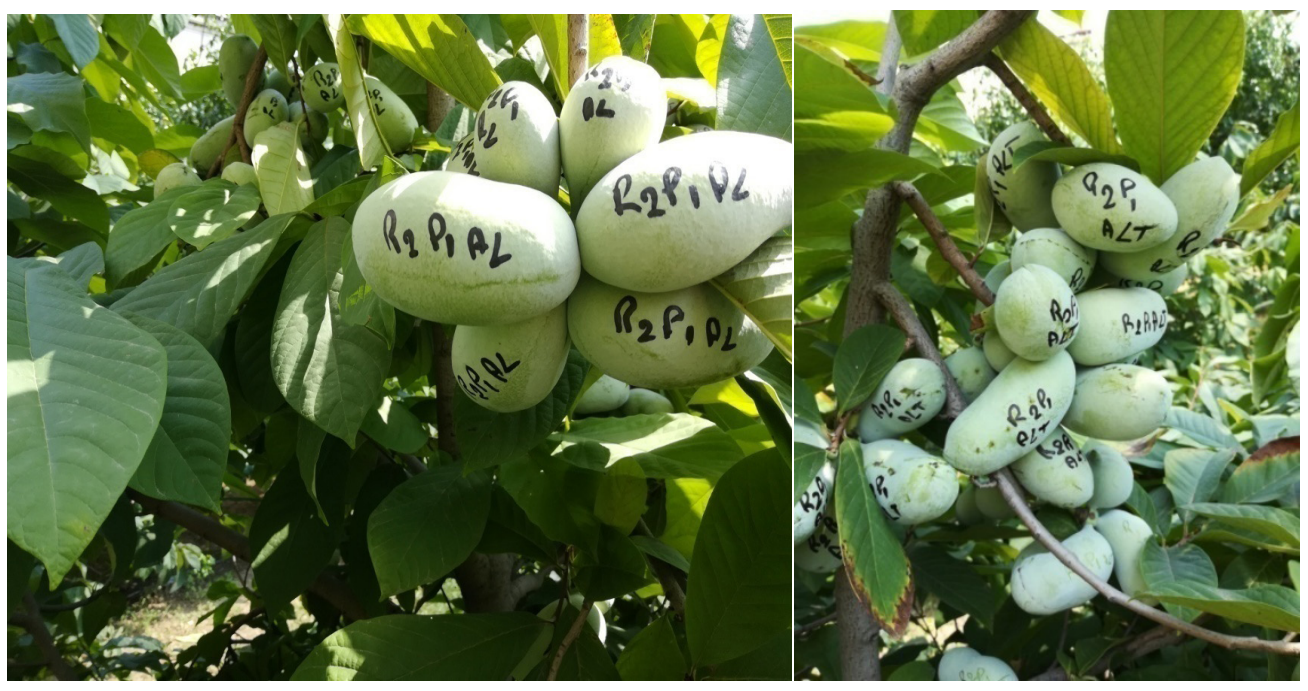

Figure 4. Fruits of 'Allegheny' cultivar 


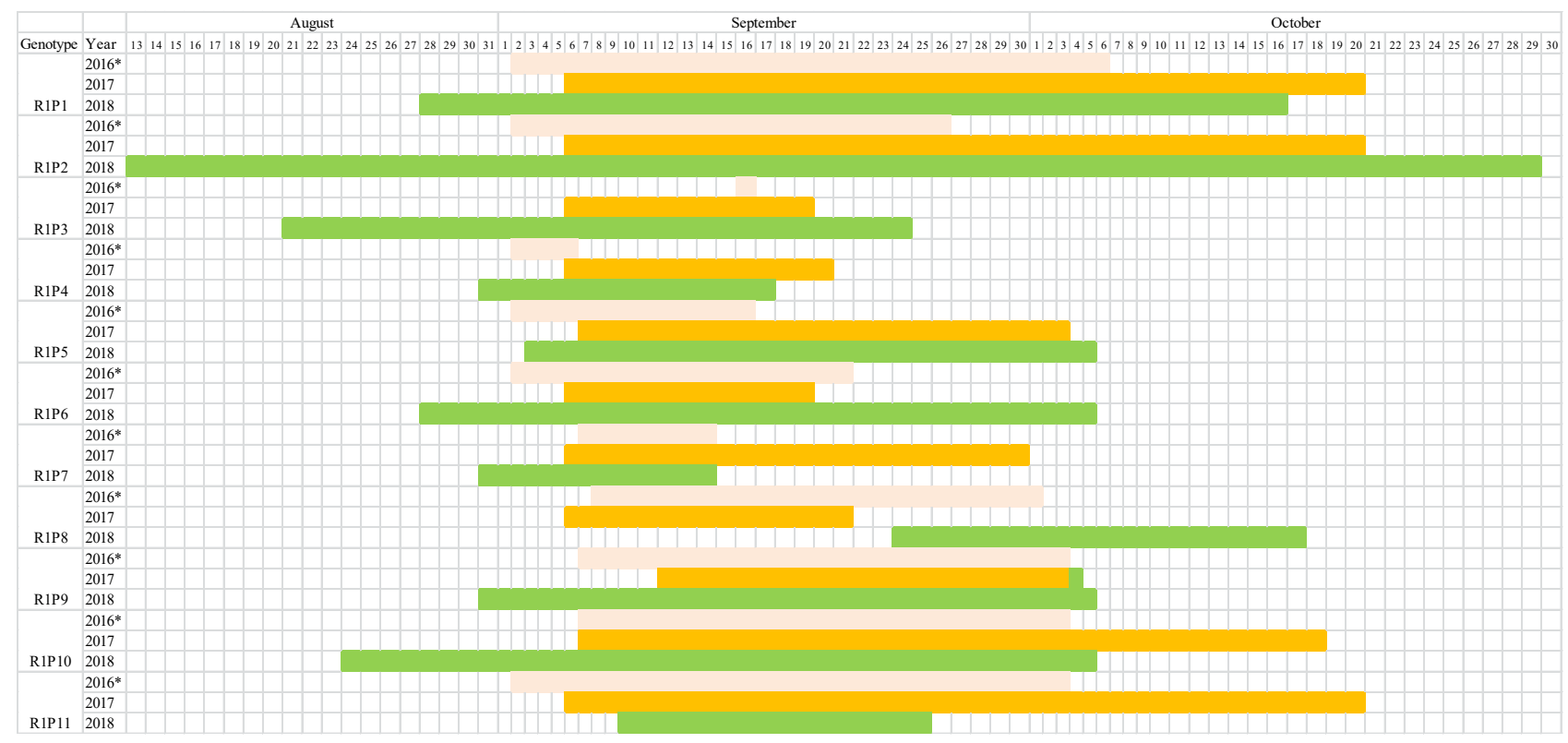

Figure 5a. Establishing harvesting period for genotypes in terms of maturation

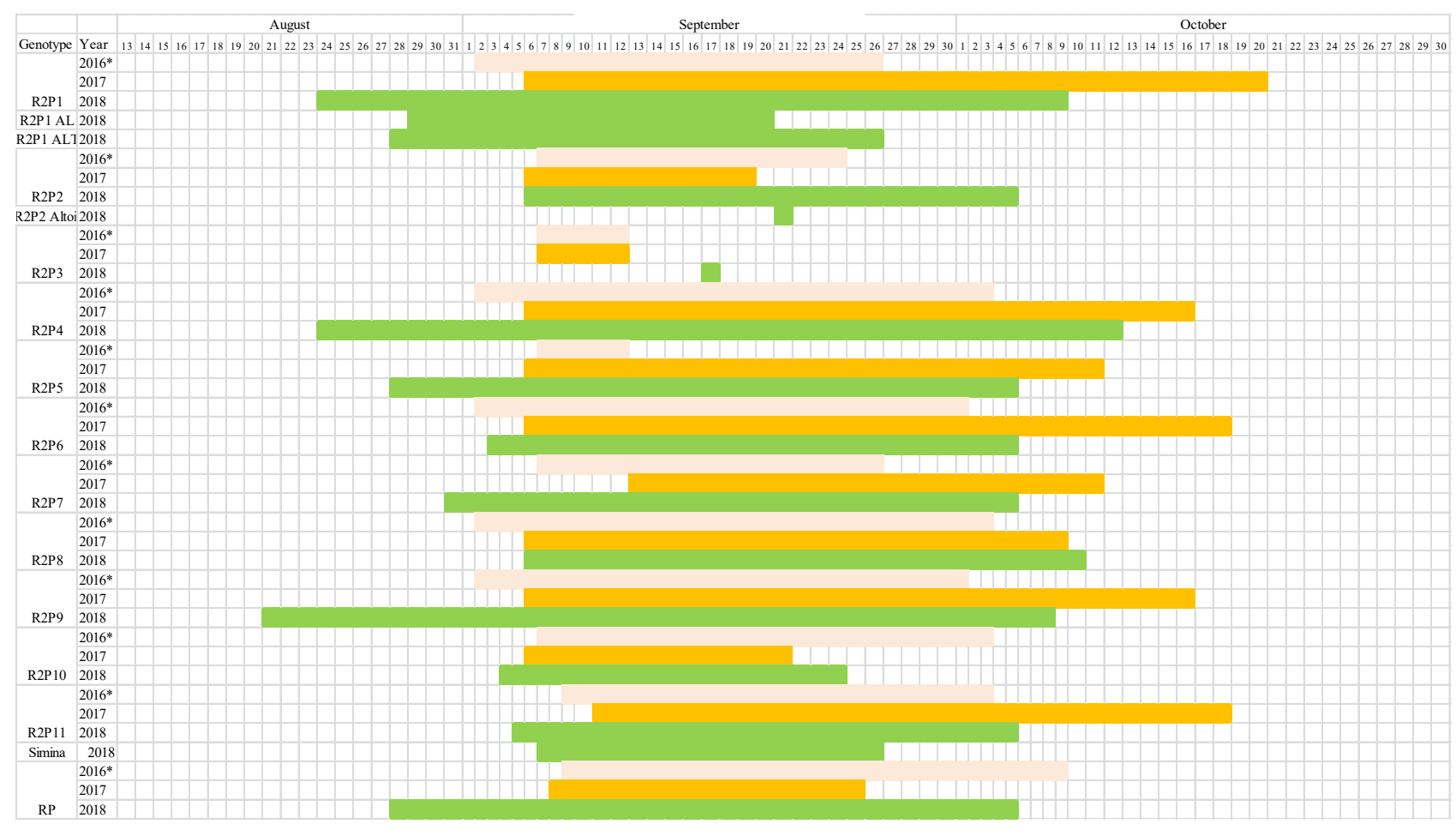

Figure 5b. Establishing harvesting period for genotypes in terms of maturation

\section{Seeds morphological characterization}

Following the determinations made for 2018 production, the average number of seeds/fruit varied according the genotype from 2 to 11 seeds (Fig. 6 and 7). The seed mass expressed in g/fruit varied from $3.7 \mathrm{~g} /$ fruit to $14.2 \mathrm{~g}$ /fruit.
The average seed weight compared to other fruit species such as apple or pear was much higher with values between 0.9 and $1.8 \mathrm{~g}$. The lowest values were obtained at R1P1 and R2P2 genotypes respectively, at 'Potomac' variety (Fig. 8 and 9). Crabtree et al. (2014) registered also the rate of the seed weight in the fruit for several 

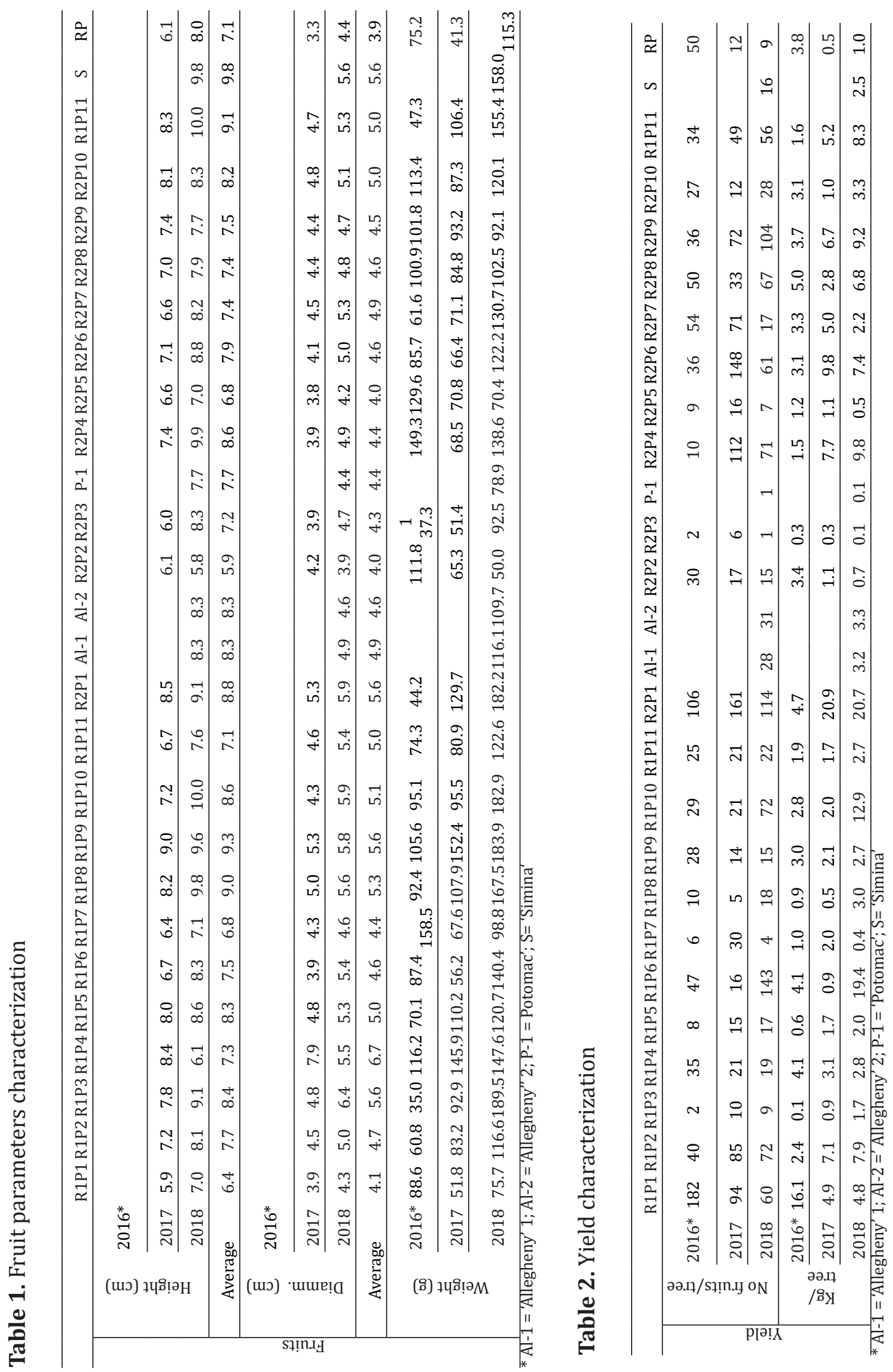


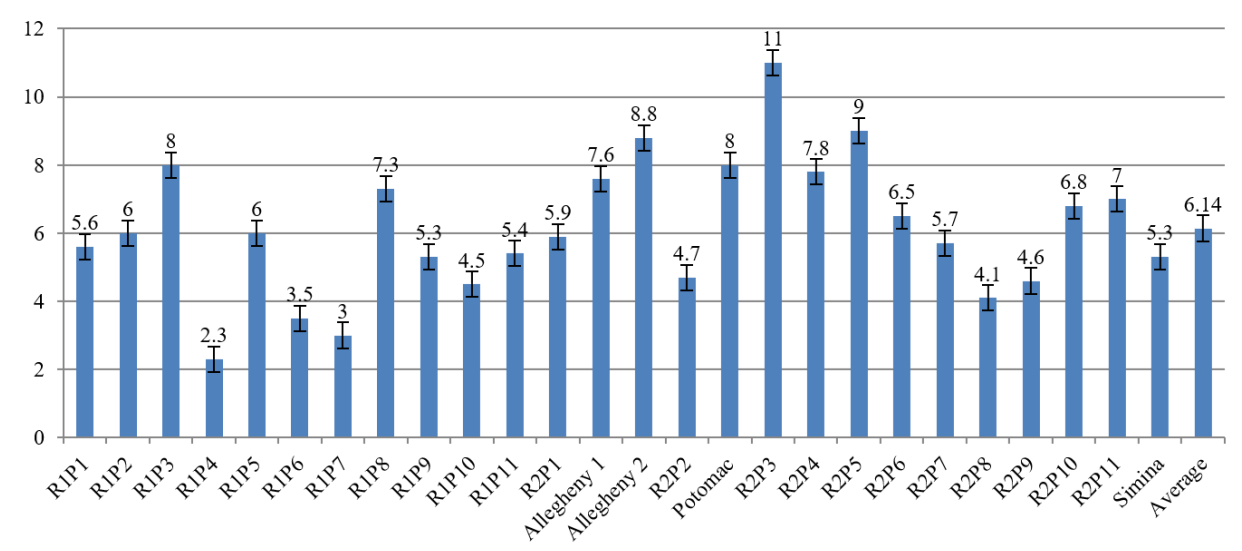

Figure 6. Seed number/fruit

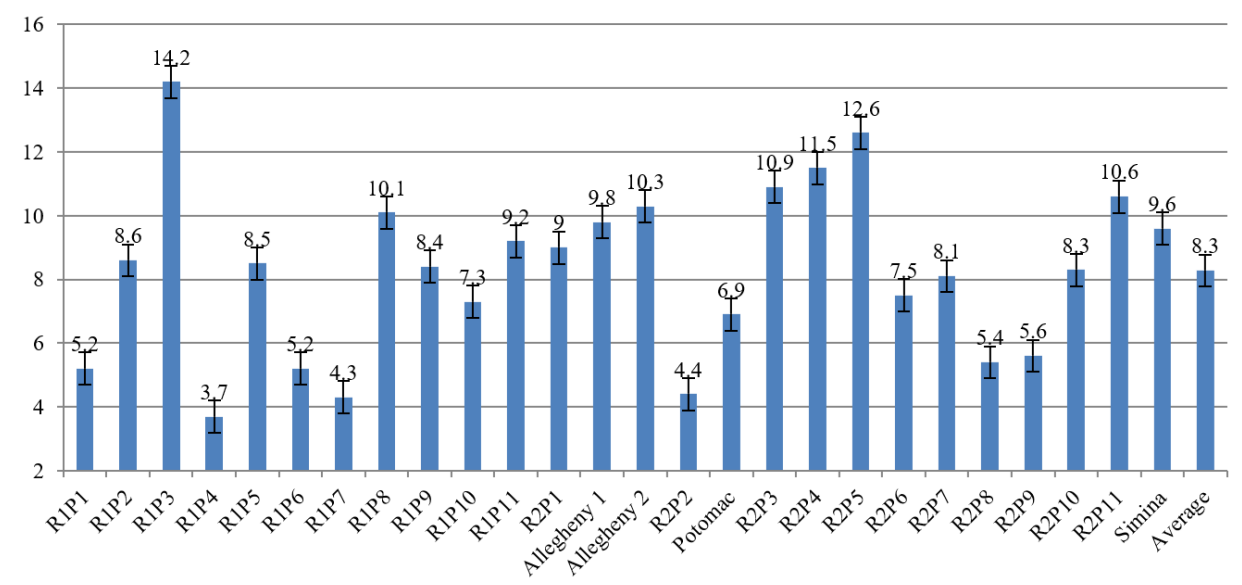

Figure 7. Seed mass (g)/fruit

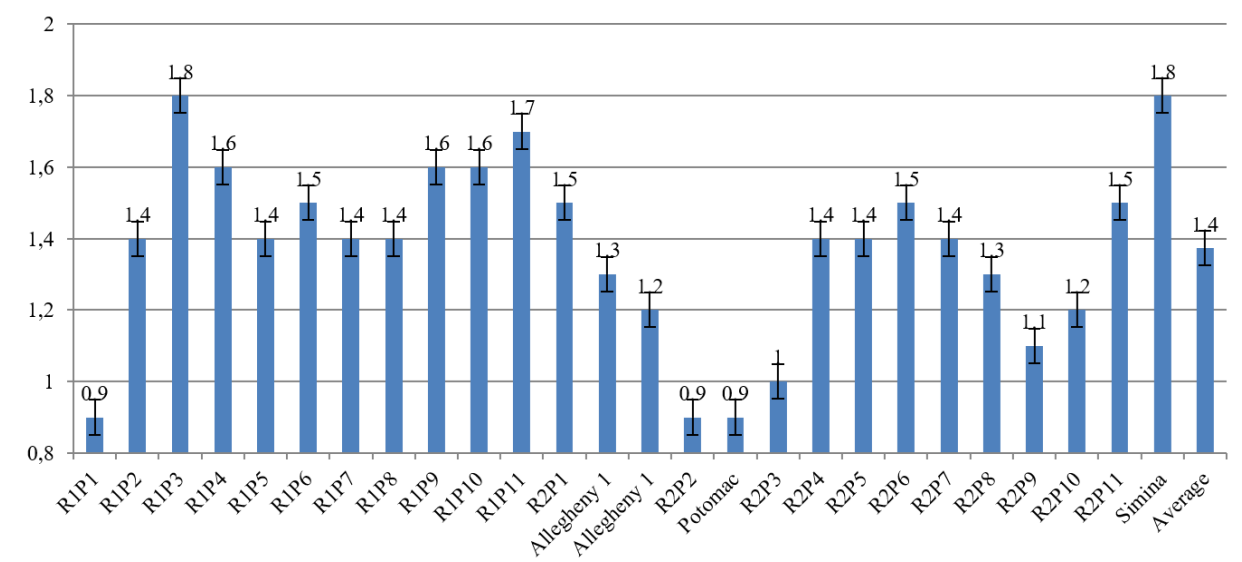

Figure 8. Average seed weight

pawpaw cultivars, highlighting the importance of its low value.

According to the data presented in Table 3, the seed height varied between 1.79 and $2.85 \mathrm{~cm}$, the average diameter varied between 1.01 and 1.25 $\mathrm{cm}$, the results of the shape index varied between 1.88 and 2.67 respectively. Following the results obtained, the seed form was elongated. Szilagy et al. (2016a) noticed an average of $1.51 \mathrm{~g} / \mathrm{seed}, 2.59$ $\mathrm{cm}$ height and $1.33 \mathrm{~cm}$ diameter. 


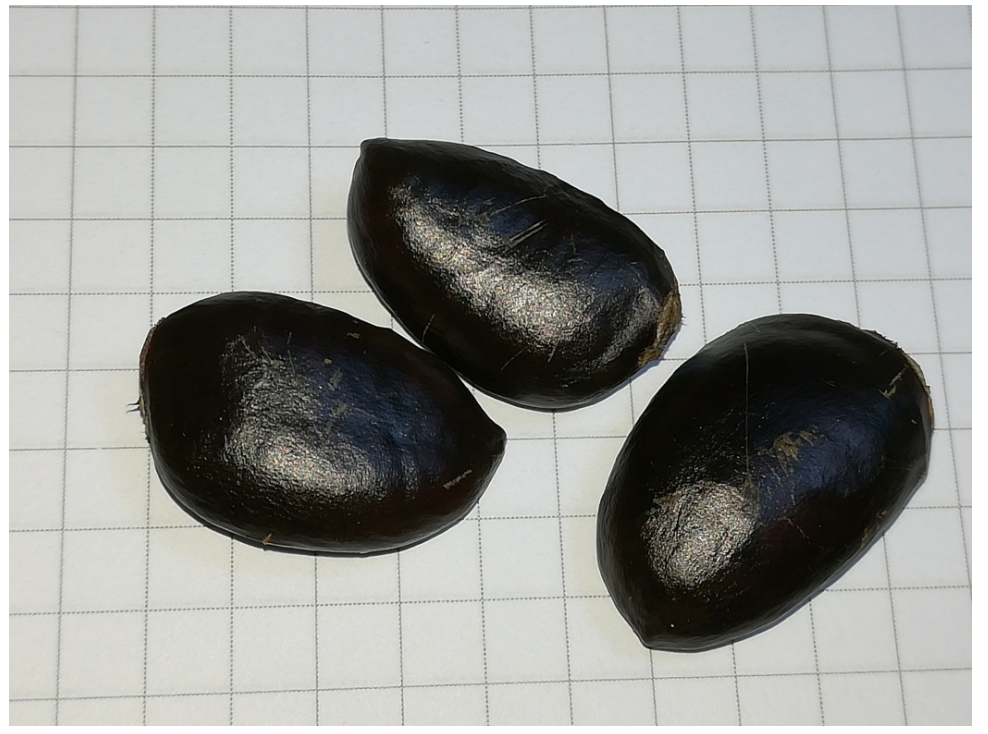

Figure 9. Seeds of R2P2 genotype

Table 3. Determining the shape of asimina seeds

\begin{tabular}{ccccc}
\hline Genotype & Height $(\mathrm{cm})$ & Diameter $(\mathrm{cm})$ & Shape index & Shape \\
\hline R1P1 & 2.13 & 1.01 & 2.11 & Elongated \\
\hline R1P6 & 1.79 & 1.01 & 1.77 & Elongated \\
\hline R1P10 & 2.57 & 1.15 & 2.24 & Elongated \\
\hline R1P11 & 2.85 & 1.07 & 2.67 & Elongated \\
\hline R2P1 & 2.56 & 1.12 & 2.28 & Elongated \\
\hline 'Allegheny' 1 & 2.39 & 1.09 & 2.21 & Elongated \\
\hline 'Allegheny' 2 & 2.28 & 1.03 & 2.22 & Elongated \\
\hline R2P2 & 2.06 & 1.05 & 1.96 & Elongated \\
\hline R2P4 & 2.39 & 1.14 & 2.11 & Elongated \\
\hline R2P6 & 2.35 & 1.25 & 1.88 & Elongated \\
\hline R2P8 & 2.25 & 1.10 & 2.04 & Elongated \\
\hline R2P9 & 2.15 & 1.05 & 2.05 & Elongated \\
\hline R2P10 & 2.60 & 1.05 & 2.46 & Elongated \\
\hline Average & 2.34 & 1.09 & 2.15 & \\
\hline
\end{tabular}

Total soluble solids and dry matter

Dry matter varied from $17.18 \%$ (R2P2) to 31.05\% (R2P8), 'Allegheny' 2 cultivar presenting a value of $9.47 \%$. R1P1, R1P4 and R1P9 presented also high values.

Total soluble solids varied from $15.40 \%$ (R2P2) to 27.90\% (R1P4) (Fig. 10).

The results are similar with Brannan et al. (2015), their studied genotypes registering total soluble solids between $19.9 \%$ and $28.0 \%$ and dry matter between $23.4 \%$ and $28.9 \%$.
Ascorbic acid content and titrable acidity in 'Allegheny' cultivar

Ascorbic acid content varied between 18.16 and $19.13 \mathrm{mg} / 100 \mathrm{~g}$ and titrable acidity between 0.08 - $0.12 \mathrm{~g}$ malic acid/100 g fresh fruit (Tab. 4).

Sensorial analysis of asimina fruits

The first test of consumer preferences was made in 2017, having five testing parameters. The most appreciated fruits were of R1P6, R2P9 and R2P10 genotypes. The most appreciated for the fruit size were R2P10 fruits while for the skin colour R1P6 genotype fruits (Tab. 5). 


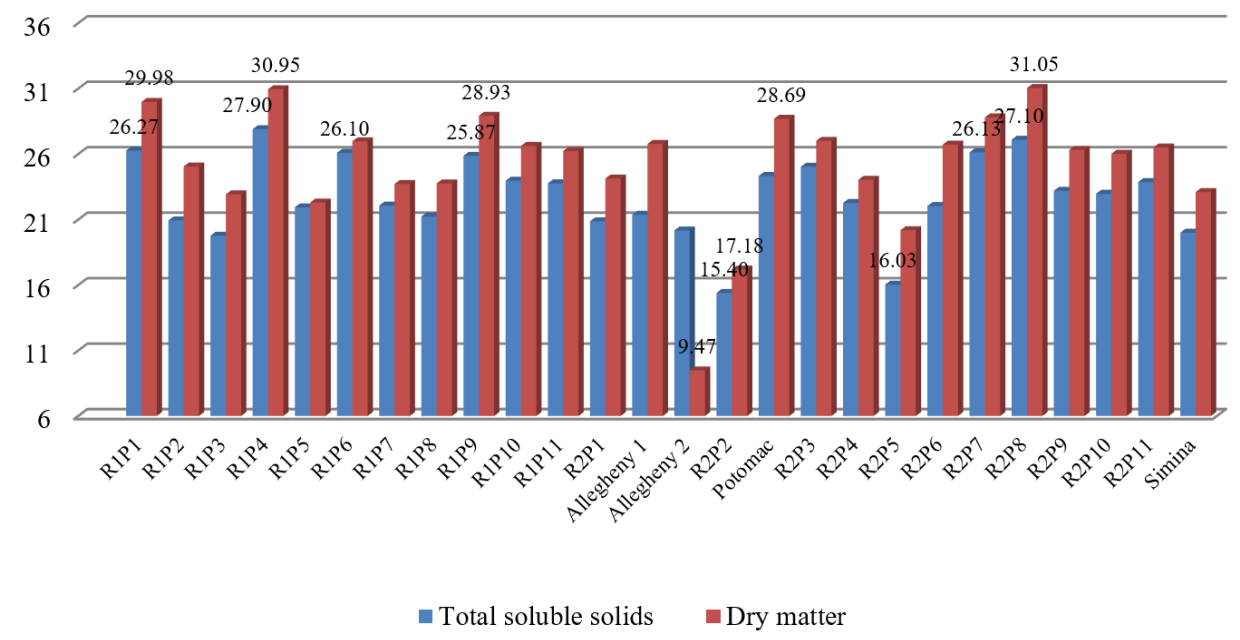

Figure 10. Total soluble solids and dry matter content

Table 4. Titrable acidity and ascorbic acid content in 'Allegheny' cultivar fruits

\begin{tabular}{ccc}
\hline Cultivar & $\begin{array}{c}\text { Titrate acidity } \\
\text { (g malic acid/100 g fresh product) }\end{array}$ & $\begin{array}{c}\text { Ascorbic acid } \\
\mathrm{mg} / 100 \mathrm{~g}\end{array}$ \\
\hline 'Alegheny' 1 & 0.12 & 18.16 \\
\hline 'Alegheny' 2 & 0.08 & 19.13 \\
\hline Average & 0.10 & 18.64 \\
\hline
\end{tabular}

Table 5. Appreciation of pawpaw fruits according to 2017 sensorial analysis

\begin{tabular}{cccccc}
\hline \multirow{2}{*}{ Genotype } & Size & Skin colour & Taste & Flavour & Total \\
& $1-10$ & $1-10$ & $1-10$ & $1-10$ & $9-40$ \\
\hline RP & 5.8 & 5.3 & 7.1 & 7.1 & 25.3 \\
\hline R2P1 & 7.5 & 7.5 & 7.0 & 8.0 & 30.0 \\
\hline R2P2 & 7.6 & 7.0 & 8.0 & 7.4 & 30.0 \\
\hline R2P4 & 5.0 & 5.0 & 9.0 & 9.0 & 28.0 \\
\hline R2P6 & 8.3 & 6.7 & 8.0 & 9.3 & 32.3 \\
\hline R2P7 & 6.4 & 5.5 & 8.0 & 8.1 & 28.0 \\
\hline R2P8 & 5.0 & 5.3 & 8.3 & 8.3 & 26.8 \\
\hline R2P9 & 7.5 & 7.9 & 9.3 & 9.6 & 34.2 \\
\hline R2P10 & 9.4 & 7.9 & 9.0 & 8.5 & 34.8 \\
\hline R1P1 & 5.8 & 4.9 & 8.1 & 7.9 & 26.7 \\
\hline R1P4 & 6.7 & 5.2 & 7.1 & 7.2 & 26.2 \\
\hline R1P6 & 7.5 & 8.3 & 9.3 & 10.0 & 35.2 \\
\hline R1P7 & 7.5 & 7.5 & 5.3 & 6.3 & 26.5 \\
\hline R1P8 & 5.0 & 5.0 & 9.3 & 8.7 & 28.0 \\
\hline R1P10 & 7.0 & 5.8 & 8.9 & 8.7 & 30.4 \\
\hline Average & 6.8 & 6.32 & 8.11 & 8.27 & 29.49 \\
\hline & & & & &
\end{tabular}


Table 6. Sensory analysis of the asimina fruits of certain genotypes (2018)

\begin{tabular}{cccccccccr}
\hline Genotype & $\begin{array}{c}\text { Fruit } \\
\text { size* } \\
(1-3)\end{array}$ & $\begin{array}{c}\text { Fruit } \\
\text { shape* } \\
(1-3)\end{array}$ & $\begin{array}{c}\text { Attractiveness* } \\
(1-5)\end{array}$ & $\begin{array}{c}\text { Pulp } \\
\text { firmness* } \\
(1-5)\end{array}$ & $\begin{array}{c}\text { Pulp } \\
\text { juiciness* } \\
(1-3)\end{array}$ & $\begin{array}{c}\text { Pulp colour* } \\
(1-3)\end{array}$ & $\begin{array}{c}\text { Taste* } \\
(1-6)\end{array}$ & $\begin{array}{c}\text { Flavour* } \\
(1-4)\end{array}$ & $\begin{array}{c}\text { Total* } \\
(1-32)\end{array}$ \\
\hline R1P1 & 2.00 & 2.00 & 2.33 & 1.33 & 2.33 & 2.33 & 3.00 & 2.33 & 17.67 \\
\hline R1P2 & 2.33 & 1.78 & 2.33 & 2.00 & 1.67 & 2.11 & 2.22 & 2.00 & 16.44 \\
\hline R1P5 & 1.80 & 1.80 & 1.40 & 1.40 & 1.20 & 1.80 & 1.60 & 2.00 & 13.00 \\
\hline R1P8 & 2.82 & 2.36 & 2.55 & 2.09 & 1.91 & 2.18 & 4.18 & 2.64 & 20.73 \\
\hline R1P9 & 1.88 & 1.63 & 1.50 & 1.75 & 1.63 & 1.50 & 2.13 & 1.50 & 13.50 \\
\hline R1P10 & 2.33 & 2.33 & 2.00 & 2.33 & 1.67 & 2.00 & 5.00 & 3.33 & 21.00 \\
\hline R2P4 & 2.00 & 2.13 & 1.88 & 2.13 & 1.88 & 1.75 & 3.38 & 2.38 & 17.50 \\
\hline R2P5 & 2.00 & 2.00 & 2.29 & 2.43 & 2.43 & 2.14 & 4.29 & 2.71 & 20.29 \\
\hline R2P6 & 2.27 & 2.27 & 2.27 & 2.00 & 2.18 & 2.00 & 3.36 & 2.45 & 18.82 \\
\hline R2P8 & 2.27 & 2.27 & 2.45 & 2.45 & 2.00 & 2.00 & 4.00 & 2.64 & 20.09 \\
\hline R2P9 & 1.89 & 2.11 & 1.56 & 2.00 & 1.78 & 2.00 & 3.78 & 2.67 & 17.78 \\
\hline R2P11 & 2.50 & 2.30 & 2.20 & 2.10 & 1.80 & 1.80 & 4.10 & 2.90 & 19.70 \\
\hline RP & 2.10 & 2.10 & 1.90 & 2.20 & 2.00 & 2.10 & 3.30 & 2.20 & 17.90 \\
\hline Average & 2.17 & 2.08 & 2.05 & 2.02 & 1.88 & 1.98 & 3.41 & 2.44 & 18.03 \\
\hline *data were statistically processed according to the rate and average calculated for each parameter & & & &
\end{tabular}

* data were statistically processed according to the rate and average calculated for each parameter

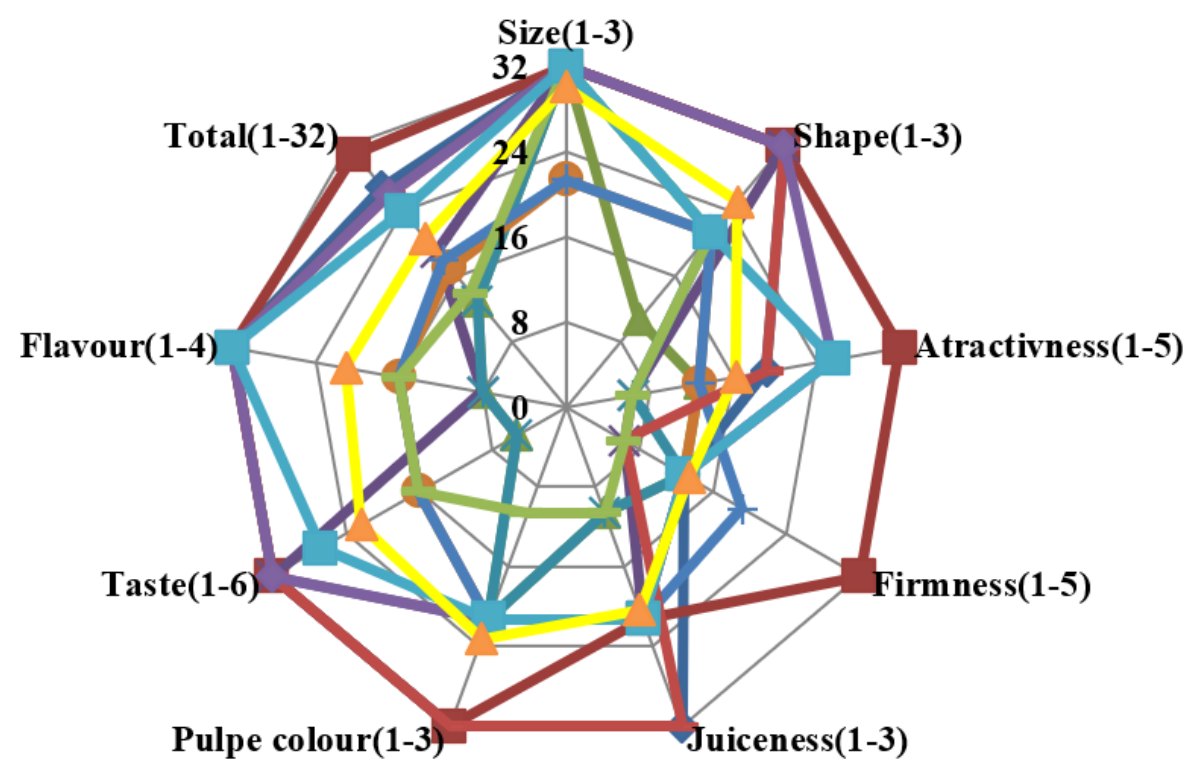

Figure 11. Parameters evaluated by sensory analysis for R1P8 genotype

For the second testing (2018), the most appreciated genotypes were R1P8 that received the best scores in terms of fruit size, fruit shape and attractive appearance; R2P8 obtained the best score from the point of view of the pulp firmness; R1P1 recorded the best score in terms of pulp colour while R1P10 accumulated the highest score in the taste and aroma criteria. The most appreciated genotype, based on the final score, was R1P10 (Tab. 6).

Some of the genotypes with the highest scores in 2018 were appreciated also in 2017, but not with the highest values. Brannan et al. (2012) noticed in pawpaw pulp sensorial analyses testing besides mango and papaya fruits that identification of pawpaw seemed to increase with increasing age, 

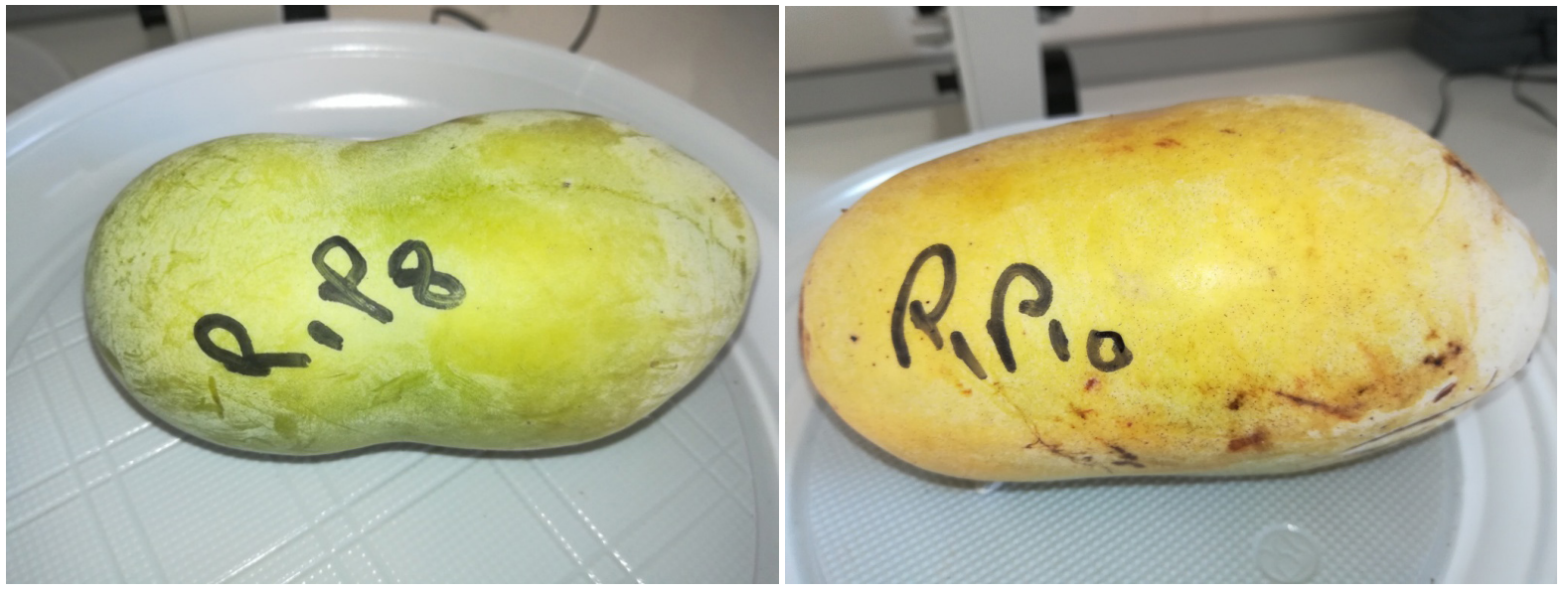

Figure 12. Fruits of the highly appreciated R1P8 and R1P10 genotypes

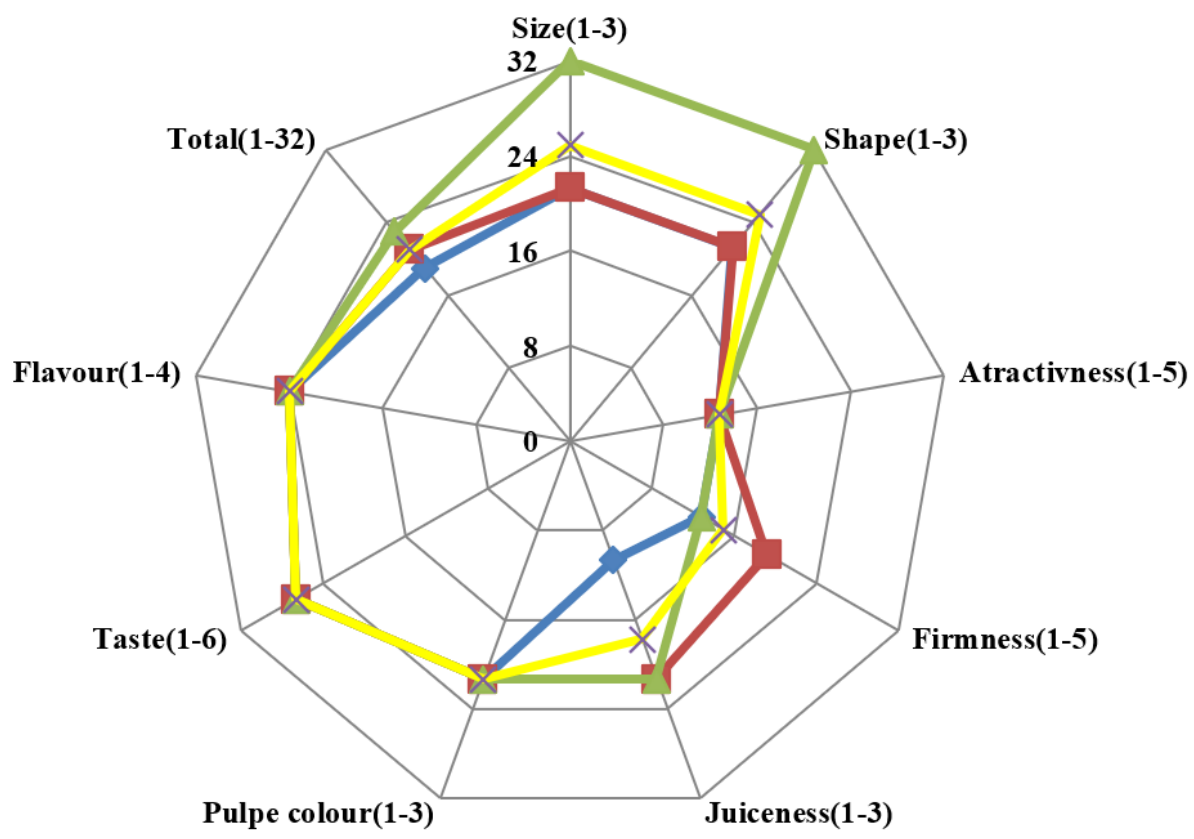

Figure 13. Parameters evaluated by sensory analysis at R1P10 genotype

education and consumption. Further researches are required to observe these characteristics.

The most appreciated criteria for the R1P8 genotype (Fig. 11 and 12) were the taste, the size of the fruit and the flavour while the least was the pulp juiciness.

The most appreciated parameters for R1P10 genotype (Fig. 12 and 13) were the taste, aroma, size and shape of the fruit. The parameter with the lowest accumulated score was the pulp firmness.

The most appreciated criteria for R2P8 genotype (Fig. 14 and 15) were the taste, aroma, attractive appearance and firmness of the pulp.
The criteria with the lowest scores were the succulence and the pulp colour.

\section{Conclusions}

This study presented a pomological description with several parameters for the genotypes from Bucharest collection, highlighting the most valuable genotypes according to the analyses performed and also to the consumer's preferences. Its qualities recommend the pawpaw as a promising fruit for diversify the present fruit species consumed in Romania and also in Europe. The measurements and the analyses recommend: 


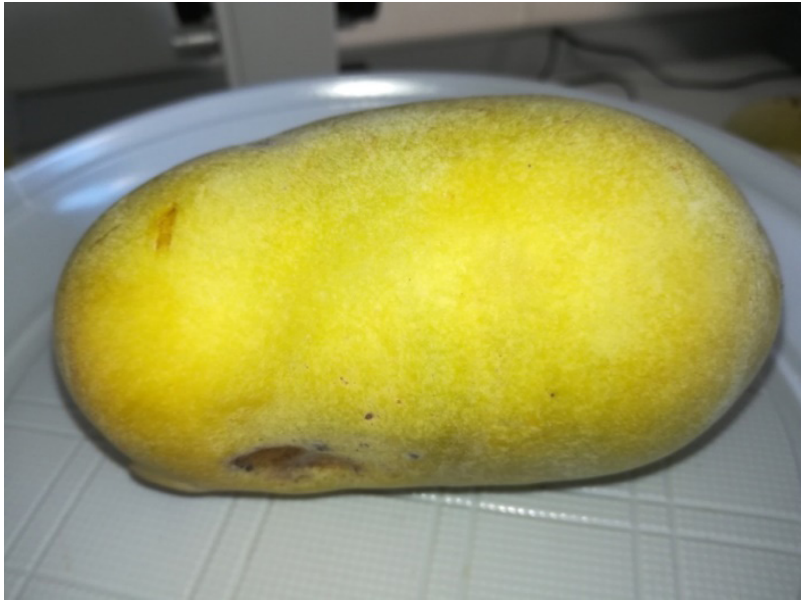

Figure 14. Fruit of the R2P8 genotype

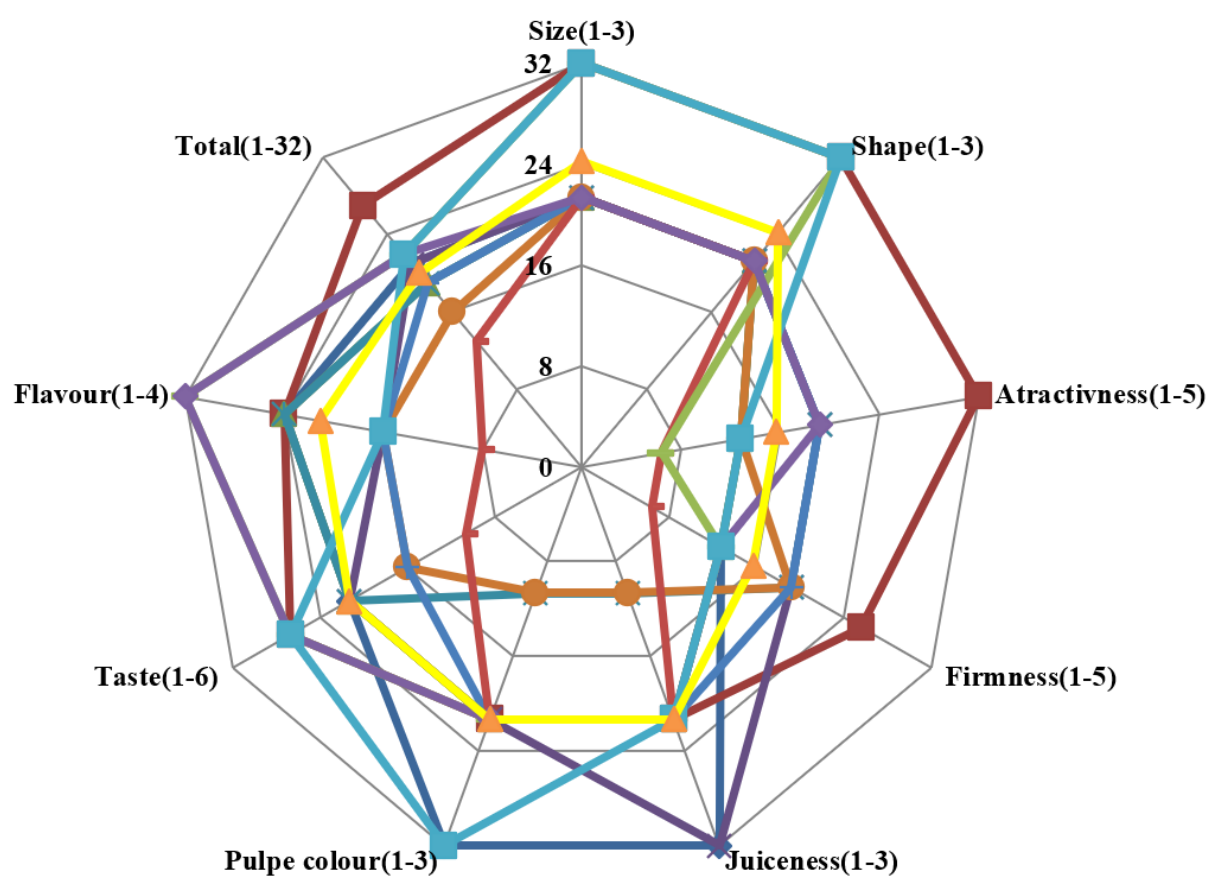

Figure 15. Parameters evaluated by sensory analysis at R2P8 genotype

for earliness and lateness: R1P2 and R1P8; yield/ tree: R1P6 and R2P1; fruits sizes: R1P3, R2P1 and R2P4; seeds sizes: R1P4 and R2P2; fruits biochemical parameters: R1P4, R2P8, R2P9 and 'Allegheny'. From the sensory analysis test, promising genotypes were: R1P10, R1P8, R2P5 and R2P8. The most valuable genotypes from the Experimental field according to the analyses performed and the consumer's preferences were taken in consideration for further research.

\section{References}

1. Avula B, Bae JY, Majrashi T, Wu TY, Wang YH, Wang M, Ali Z, Wu YC, Khan IA (2018). Targeted and non-targeted analysis of annonaceous alkaloids and acetogenins from Asimina and Annona species using UHPLC-QToF-MS. Journal of Pharmaceutical and Biomedical Analysis, 159: 548-566.

2. Bezdadea Cătuneanu I, Bădulescu L, Dobrin A, Stan A, Hoza D (2017). The influence of storage in controlled atmosphere on quality indicators of three blueberries varieties. Scientific Papers. Series B, Horticulture, LXI: 91100.

3. Brannan RG, Salabak DE, Holben DH (2012). Sensory Analysis of Pawpaw (Asimina triloba) Pulp Puree: 
Consumer Appraisal and Descriptive Lexicon. Journal of Food Research 1(1): 179-182.

4. Brannan RG, Peters T, Talcott ST (2015). Phytochemical analysis of ten varieties of pawpaw (Asimina triloba [L.] Dunal) fruit pulp. Food Chemistry, 168: 656-661.

5. Cepoiu N, Dănăilă-Guidea S M, Burzo I, Roșu A, Margarit C, Păun C (2004). Morpho-Productive Particularities of Local Population (PGO) of Asimina triloba (L.) Dunal, from Romania. Scientific Papers U.S.A.M.V.B., Seria B, XLVII: 306-311.

6. Chanforan C, Loonis M, Mora N, Caris-Veyrat C, Dufour C (2012). The impact of industrial processing on healthbeneficial tomato microconstituents, Food Chemistry 134: 1786-1795.

7. Corollaro ML, Aprea E, Endrizzi I, Betta E, Demattè ML, Charles M, Bergamaschi M, Costa F, Biasioli F, Grappadelli LC, Gasperi F (2014). A combined sensory-instrumental tool for apple quality evaluation. Postharvest Biology and Technology, 96: 135-144.

8. Cotruţ RC, Stănică F, Burzo I, Nicolae D (2005). The Biochemical Fruits Composition to Some Selection of Asimina triloba (L.) Dunal. Scientific Papers. Series B, Horticulture, XLVIII: 250-254.

9. Crabtree SB, Pomper KW, Lowe J D, May BK (2014). Pulp recovery from North American Pawpaw fruit [Asimina triloba (L.) Dunal]. Journal of the American Pomological Society, 68(2): 111-115.

10. Delian E, Petre V, Burzo I, Bădulescu L, Hoza D (2011). Total phenols and nutrients composition aspects of some apple cultivars and new studied breeding creations lines grown in Voinești area - Romania. Romanian Biotechnological Letters, 16: 6722-6729.

11. Ghena N, Braniște N, Stănică F (2004). General Pomology. Bucharest: RO, Matrix Rom Publishing House.

12. Kral R (1960). A revision of Asimina and Deeringothammus (Anonnaceae), Brittonia. 12 (4): 233.

13. Koslanund R, Archbold DD, Pomper KW (2000). Ripening and the Climacteric of Pawpaw. Hortscience 35(4): 560E-560d.

14. Hoza D (2014). Pomology. Bucharest, RO: Ex Terra Aurum Publishing House.

15. Huang H, Layne DR, Kubisiak TL (2003). Molecular Characterization of cultivated pawpaw (Asimina triloba) using RAPD Markers. Journal of American Society Horticulture, 128(1): 85 - 93.

16. Johnson HA, Gordon J, McLaughlin JL (1996). Monthly variations in biological activity of Asimina triloba. Journal Janick, Progress in new crops: Proceedings of the Third National Symposium, ASHS Alexandria, VA: 609-614.

17. Layne DR (1996). The pawpaw (Asimina triloba (L.) Dunal): A new fruit crop for Kentucky and the United States, HortScience, 31(5): 777-784.

18. McLaughlin J, Rupprecht K, Chang C, Cassady J, Mikolkajczak K, Weisleder D (1986). Asimicin, a New Cytotoxic and Pesticidal Acetogenin from the Pawpaw, Asimina triloba (Annonaceae). Heterocycles. 24: 1197-1201.
19. Moura C, Masson M, Yamamoto C (2005). Effect of osmotic dehydration in the apple (Pyrusmalus) varieties Gala, Gold and Fuji. Thermal Engineering, 4: 46-49.

20. Mureşan E, Muste S, Borşa A, Vlaic R, Mureşan V (2014). Evalution of physical-chemical indexes, sugars, pigments and phenolic compounds of fruits from three apple varieties at the end of storage period. Bulletin UASVM Food Science and Technology 71(1): 45-50.

21. Nam JS, Jang HL, Rhee YH (2018). Nutritional compositions in roots, twigs, leaves, fruit pulp, and seeds from pawpaw (Asimina triloba [L.] Dunal) grown in Korea. Journal of Applied Botany and Food Quality 91: 47 - 55.

22. Oltenacu N, Lascăr E (2015). Capacity of maintaining the apples quality, in fresh condition-case study. Scientific Papers Series Management, Economic Engineering in Agriculture and Rural Development, 15: 331-335.

23. Pomper KW, Crabtree SB, Brown SP, Jones SC, Bonney TM, Layne DR (2003). Assessment of Genetic diversity of pawpaw (Asimina triloba) cultivars with Intersimple sequence repeat markers. Journal American Society Horticulture 128 (4): 521-525.

24. Pomper KW, Crabtree SB, Layne DR, Peterson RN (2008). Flowering and Fruiting Characteristics of Eight Pawpaw [Asimina triloba (L.) Dunal] Selections in Kentucky. Journal of the American Pomological Society, 62(3): 89-97.

25. Ratnayake S, Rupprecht JK, Potter WM, McLaughlin JL (1993). Evaluation of the pawpaw tree, Asimina triloba (Annonaceae), as a commercial source of the pesticidal annonaceous acetogenins. J. Janick and J.E. Simon (eds.), New crops. Wiley, New York: 644-648.

26. Saei A, Tustin D, Zamani Z, Talaie A, Hall A (2011). Cropping effects on the loss of apple fruit firmness during storage: The relationship between texture retention and fruit dry matter concentration. ScientiaHorticulturae, 130: 256-265.

27. Skupień K (2006). Chemical composition of selected cultivars of highbush blueberry fruit (Vaccinium corymbosum L.). Folia Horticulturae, 18(2): 47-56.

28. Stănică F, Cepoiu N (2003). Northern banana (Asimina triloba (L.) Dunal) - a new fruit specie in Romania, Scientific Papers. Series B, Horticulture, XLVI: 208-211.

29. Stănică F, Ghena N, Dănăilă-Guidea S, Cotruţ R (2004). Preliminary results regarding the propagation by grafting of northern banana (Asimina triloba (L.) Dunal. Scientific Papers. Series B, Horticulture, XLVII: 371-377.

30. Stănică F, Cotruţ R, Zuccherelli G (2008). New Selections of PawPaw (Asimina triloba (L) Dunal). Acta Horticulturae, 772: 203-206.

31. Stănică F (2012). Asimina triloba (pawpaw) germplasm in Romania. Scientific Papers, Series B. Horticulture, LVI: 267-272.

32. Szilagyi BA, Marian M (2011). Morphological and physiological features of the species Asimina triloba (L.) Dunal, introduced as an ornamental plant in Baia Mare (Maramureș county, Romania). Analele Universităţii din Oradea - Fascicula Biologie Tom. XVIII (2): 168-175.

33. Szilagyi BA, Stănică F, Dănăilă-Guidea SM (2016a). Study the morphology of Asimina triloba (1.) Dunal fruits and 
seeds obtained in the Transylvania region of Romania. Current Trends in Natural Sciences 5(9): 79-83.

34. Szilagyi BA, Stănică F, Dănăilă-Guidea SM, $2016 \mathrm{~b}$. Flowering of Asimina triloba (L.) Dunal in the conditions of Transylvania. Proceedings of the 23rd International Conference of the Oltenia Museum, XXXII (1):.50-54.

35. Szilagyi BA, Stănică F, Dănăilă-Guidea SM (2017). Evaluation of morphological parameters of flowering buds and flowering on Asimina triloba (L.) Dunal in the context of climate change in Romania. Current Trends in Natural Science, 6 (11): 122-127.

36. Ștefan N, Glăman G, Braniște N, Stănică F, Duțu I, Coman M (eds.) (2018). Pomologia României X [Romanian Pomology X]. Bucharest, RO: Ceres Publishing House.
37. Ticha A, Salejda A, Hyšpler R, Matejicek A, Paprstein F, Zadak Z (2015). Sugar composition of apple cultivars and its relationship to sensory evaluation. Nauka. Technologia. Jakość, 4(101): 137-150.

38. Turmanidze T, Jgenti M, Gulua L, Shaiashvili V (2017). Effect of ascorbic acid treatment on some quality parameters of frozen strawberry and raspberry fruits, Annals of Agrarian Science 15: 370-374.

39. Yoon KY, Woodams EE, Hang YD (2005). Relationship of acid phosphatase activity and Brix/acid ratio in apples. Lebensm.-Wiss. u.-Technol, 38: 181-183.

40. Willson MF, Schemske DW (1980). Pollinator lumination, fruit production, and floral display in Pawpaw (Asimina triloba (L.) Dunal), Buletin of The Torrey Botanical Club, 107: 401-408. 